\title{
Five years of conserving the 'world's rarest snake', the Antiguan racer Alsophis antiguae
}

\author{
Jenny C. Daltry, Quentin Bloxam, Gillian Cooper, Mark L. Day, John Hartley, McRonnie Henry, \\ Kevel Lindsay and Brian E. Smith
}

\begin{abstract}
The Critically Endangered Antiguan racer Alsophis antiguae is confined to Great Bird Island, a 9.9ha (24.5-acre) islet off the north-east coast of Antigua in the Lesser Antilles. This island represents well under 0.1 per cent of the species's historical distribution range. During the past 5 years, the total number of racers aged 1 year or more has fluctuated between 51 and 114, and currently stands at approximately 80 . Since 1995, the Antiguan Racer Conservation Project (ARCP) has endeavoured to save this harmless snake from extinction by using a combination of education, conservation breeding, habitat restoration, local capacity building and applied research. The Antiguan racer's ecology and population dynamics have become well understood after 5 years of intensive study, and the species has
\end{abstract}

\section{Introduction}

Within the space of little more than a century, the distribution range of the Antiguan racer Alsophis antiguae has contracted to well under 0.1 per cent of its former size. This harmless colubrid snake used to be abundant throughout the Lesser Antillean island of Antigua and its many satellite islands (a total area of $282 \mathrm{sq} \mathrm{km}$ ), but its numbers were decimated by the Asian mongoose Herpestes javanicus, which was introduced to Antigua in the late nineteenth century (Henderson, 1989). There is sub-fossil evidence that the Antiguan racer also naturally occurred on the neigh-

Jenny C. Daitry (corresponding author) and Mark L. Day Fauna \& Flora International, Great Eastern House, Tenison Road, Cambridge CB1 2TT, UK. Tel: +44 1223 571000; e-mail: jenny.daltry@fauna-flora.org

Quentin Bloxam and John Hartley Durrell Wildlife Conservation Trust, Les Augrès Manor, Trinity, Jersey JE3 5BP, Channel Islands

Gillian Cooper Environmental Awareness Group, PO Box 2103, St John's, Antigua, West Indies

McRonnie Henry Forestry Division, Ministry of Agriculture, Forestry and Fisheries, Nevis Street, St John's, Antigua, West Indies

Kevel Lindsay Island Resources Foundation, National Museum of Antigua \& Barbuda, Long Street, St John's, Antigua, West Indies

Brian E. Smith Black Hills State University, Department of Biology, 1200 University Street Unit 9044, Spearfish, SD 57799-9044, USA

Revised manuscript accepted for publication 30 November 2000 evidently benefited from the project's rat eradication programme. The snakes are still seriously threatened by other intrinsic and extrinsic factors, however, including inbreeding depression, frequent hurricanes, invasive predators and deliberate killing by tourists, as well as the problem that Great Bird Island is too small to support more than about 100 individuals. This paper describes the activities and impact of this project to date, and outlines a series of conservation activities to safeguard the long-term future of the species, which include reintroduction of the Antiguan racer to restored islands within its former distribution range.

Keywords Alsophis, Antigua, Antiguan racer, conservation, invasive species, reintroduction.

bouring island of Barbuda, an additional area of 160 sq km (Pregill et al., 1994).

Parker (1936) declared the Antiguan racer extinct, but in fact a small colony still survived on Great Bird Island, a small mongoose-free islet $2.5 \mathrm{~km}$ off the north-east coast of Antigua (Fig. 1). Three specimens were collected from Great Bird Island during the 1960s (Lazell, 1967) and a fourth by Henderson (1989). International awareness of the Antiguan racer's plight was first raised in Oryx by Sajdak \& Henderson (1991), although the species did not become listed as Critically Endangered until 1996 (IUCN, 1996).

Only 9.9 ha (24.5 acres) in area, Great Bird Island (Plate 1) is formed largely of coralline limestone, with 30-m high cliffs on the Atlantic side. More than onethird of the island is covered with dry littoral forest with a maximum canopy height of rarely more than $6 \mathrm{~m}$. The centre of the island is low lying and sandy, with a sparse cover of grasses, agaves and trees. Both the littoral forest and sandbar vegetation communities are nationally uncommon and vulnerable (Horwith \& Lindsay, 1997).

In 1995, at the behest of the Antiguan Forestry Unit, Ministry of Agriculture, Forestry \& Fisheries, a 6-week survey was conducted on Great Bird Island to assess the status of the Antiguan racer. Using methods outlined below, the survey estimated that approximately $51 \pm \mathrm{SE}$ 7 adult and subadult racers were present on the island, with a highly skewed male: female ratio of $1: 1.8$ (Daltry \& Day, 1997). Introduced black rats Rattus rattus 


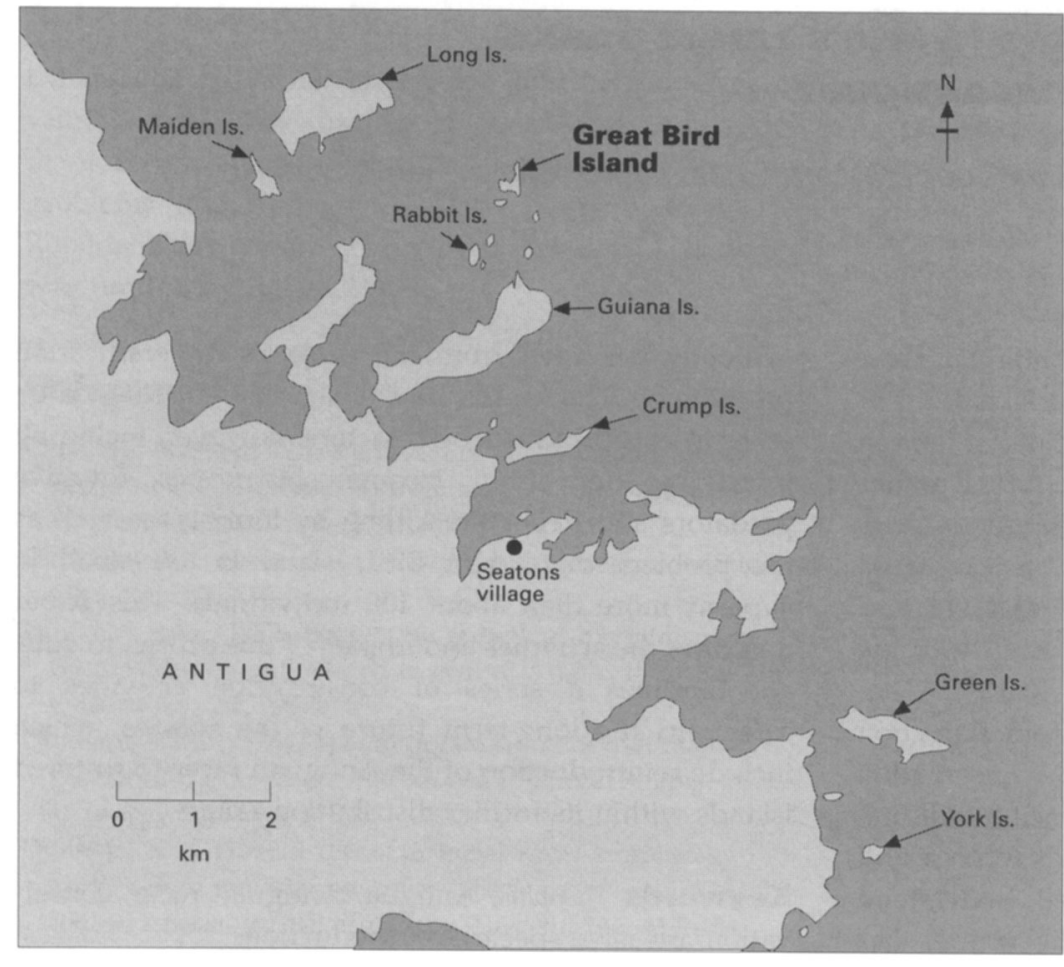

Fig. 1 North-eastern Antigua, showing the offshore islands.

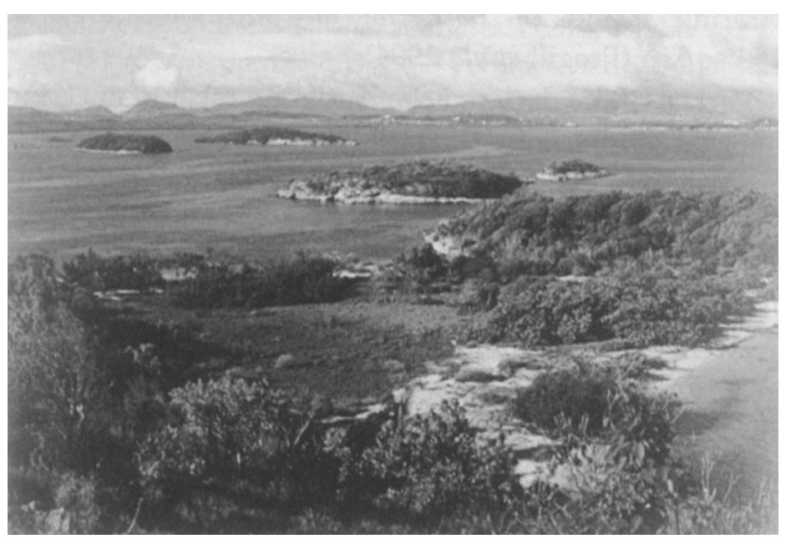

Plate 1 Great Bird Island (Mark L. Day).

had seriously injured more than half of the population (see below).

This alarming finding led to the immediate formation of the Antiguan Racer Conservation Project (ARCP). The project is managed by a partnership of six national and international organizations: Antiguan Forestry Unit, Environmental Awareness Group, Durrell Wildlife Conservation Trust, Fauna \& Flora International, Island Resources Foundation and Black Hills State University. The mission statement of the project is 'to conserve the critically endangered Antiguan racer snake and other indigenous flora and fauna of the offshore islands of Antigua and Barbuda. The ARCP uses an integrated approach that combines biological research, public education, skills transfer, ecological restoration, conservation breeding and habitat management'.

This paper outlines some of these diverse activities of the ARCP and assesses its impact to date. To begin with, however, it is helpful to review what is currently known of the natural history of the Antiguan racer and its main threats.

\section{Autecology}

\section{Morphology}

Schwartz \& Henderson (1991) and Henderson et al. (1996) provide detailed accounts of the morphology of the Antiguan racer. One of this species's most unusual characteristics is that males and females differ markedly in colour hue and pattern: males are typically dark brown with creamy blotches, whereas females are silvery grey with pale brown blotches and stripes (Plate 2). Such conspicuous sexual dichromaticism is rare among snakes, especially species of the Colubridae (e.g. Shine, 1993). Female racers also tend to be much larger than males: maximum recorded snout-vent lengths (SVL) are $990 \mathrm{~mm}$ (females) and $595 \mathrm{~mm}$ (males), and maximum body masses are $760 \mathrm{~g}$ (females) and $122 \mathrm{~g}$ (males). 


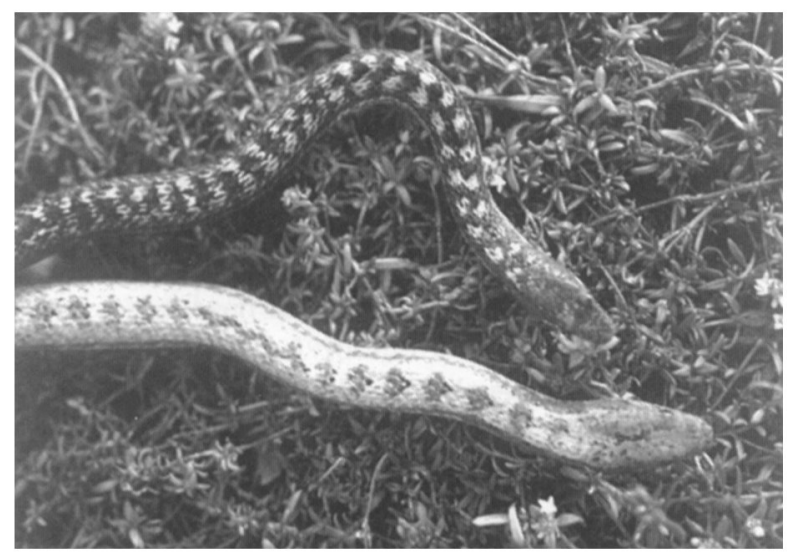

Plate 2 Male (top) and female (bottom) Antiguan racers (Mark L. Day).

A total of 169 individuals have been captured since 1995 as part of the ARCP research programme (see below), 159 of which have been permanently marked with $14 \mathrm{~mm}$ passive integrated transponder (PIT) tags to enable project staff to monitor individual growth rates and survivorship. Eighty individuals were captured in 2 or more years and these exhibited highly variable growth rates between captures. Even within each gender, neither body length nor mass can be used as a reliable indicator of the age of adults.

The 1995 assessment found that more than 50 per cent of the racers were scarred with marks consistent with rat bites and 42 per cent had incomplete tails. In extreme cases, less than one-third of the tail remained (Day \& Daltry, 1996a). Given that the hemipenes and retractor muscles are situated in the tail, it was questionable whether some of the more badly injured males were still capable of reproducing. After project personnel removed rats from the island in late 1995 (see below), the high incidence of scars and amputated tails steadily declined in the snake population as a whole. It is now very unusual to find a young racer with any signs of injury (Daltry, 1999; Ross, 2000).

\section{Population size and sex ratio}

Five near-annual censuses to assess population size and demographic structure have been carried out since 1995. The total number of racers was estimated using markrecapture, with one or two researchers spending 5 weeks on the island each year to hand-catch, mark and release the snakes. Up to eight, but more usually three, individuals were captured during $8 \mathrm{~h}$ of search effort each day, and up to 132 captures (including recaptures of the same individual) were made during each census. The racers were marked using PIT tags, and population size was estimated using Begon's
Weighted Mean (Begon, 1979). This estimator uses data collected over a number of days and makes the reasonable assumption that the population is closed and has neither births nor deaths for the duration of the study. Additionally, like most mark-recapture models, Begon's Weighted Mean estimator assumes that all individuals are equally likely to be caught. This appears to be true of the Antiguan racer population with the notable exception of juveniles (SVL $<350 \mathrm{~mm},<1$ year of age). Few juveniles have been found and only one has ever been recaptured during the same year. This sector of the population is therefore excluded from the censuses, and the estimated population size refers to adults and subadults only.

Censuses conducted in 1995, 1997, 1998, 1999 and 2000 found dramatic changes in the size of the wild Antiguan racer population (Fig. 2). The estimated number of individuals of more than 1 year of age was only 51 in November 1995, but had risen to 114 by early 1997, probably because of the eradication of black rats from the island at the end of 1995 (Daltry \& Day, 1997). Racer numbers had fallen to 81 by early 2000 , possibly in response to both decreased prey abundance and severe flooding of Great Bird Island during Hurricane Georges in September 1998 (Cooper et al., 1998). The population's sex ratio steadily improved during the same period, from a severely unbalanced ratio of 1.8 females to every male in 1995 to $1.5: 1$ in 1997, and $1: 1$ in 1999 (Daltry, 1999).

\section{Feeding ecology}

Unlike almost every other colubrid snake, the Antiguan racer is primarily an ambush hunter (Daltry \& Day,

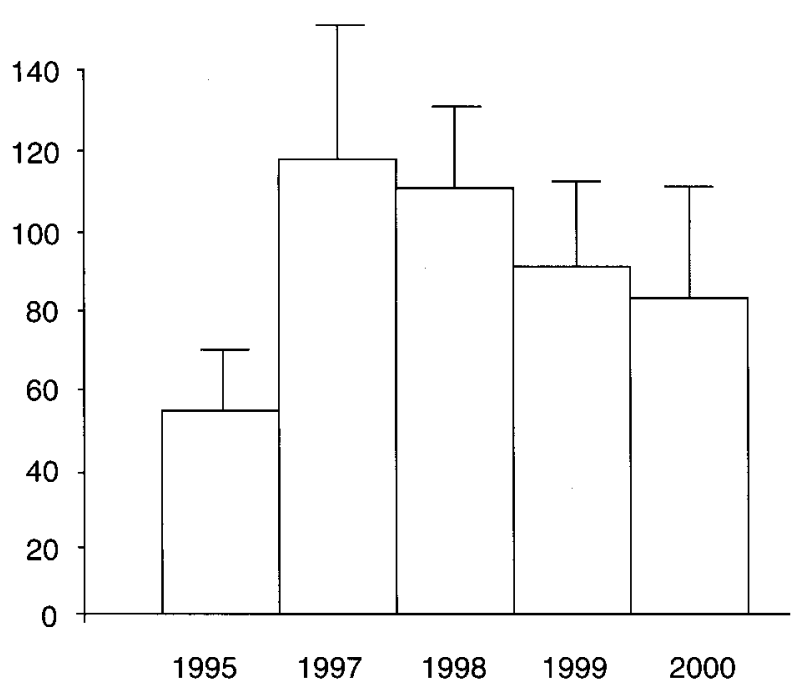

Fig. 2 Total number of Antiguan racers aged 1 year or more, estimated using mark - recapture. The SE of each estimate is shown. 
1997). Radiotelemetry studies and observations of captive individuals by Broad (1996) have demonstrated that racers spend much of the day lying beneath a thin layer of leaf litter with only their heads protruding. As soon as a passing lizard has been caught and eaten, the snake typically retreats below ground for several days.

Analysis of faeces from 73 individuals indicated that adult Antiguan racers feed mainly on lizards of the genus Anolis, with 41.1 per cent of the faecal pellets containing the body scales of the two species that inhabit Great Bird Island: Watts' anole A. wattsi and, to a lesser extent, the spotted anole $A$. bimaculatus. Scales of the Antiguan ground lizard Ameiva griswoldi, an endemic and potentially threatened species in its own right, were present in 30.1 per cent of the faecal samples, and 4.1 per cent of the samples (all from juvenile racers) contained scales from the dwarf gecko Sphaerodactylus elegantulus. A further 23.3 per cent of the faecal samples, contained lizard scales that could not be reliably attributed to any one of these four species.

Not surprisingly, the relatively large increase in snake numbers in the late 1990 s appeared to have a negative impact on the population sizes of its two main prey species - Watts' anoles and Antiguan ground lizards that in turn impaired the snakes' hunting success. Adult lizards were conspicuously more abundant on Great Bird Island in 1995-1997 than in 1998 and 1999. During the former years, only 1.8 per cent of all snakes weighed (110 measurements of 92 individuals) had protruding ribs and were considered seriously underweight, but this figure soared to 17 per cent in 1998 and 1999 (132 measurements of 93 individuals), with medium-sized adults of snout-vent length $500-700 \mathrm{~mm}$ being the worst affected. A detailed, quantitative lizard monitoring programme is currently underway to investigate the predator-prey relationship more closely, but these preliminary observations indicate that the prey populations on this island cannot sustain more than approximately 100 Antiguan racers for extended periods (ARCP, 1999).

\section{Habitat use and activity patterns}

Behavioural studies using radiotelemetry and direct observational techniques have shown that the Antiguan racer is strictly diurnal and chiefly ground dwelling. Radiotelemetry of five adults (10 per cent of the population) in 1995 demonstrated that the racers were only moderately active. The largest recorded activity range, measured using the minimum convex polygon method of Southwood (1966), was $4425 \mathrm{~m}^{2}$, based on 160 fixes over 40 days of tracking (Daltry \& Day, 1997). The recorded activity ranges steadily increased with time, however, and it is probable that every individual covers the whole island during its lifetime. Habitat association studies revealed a significant preference for a highpercentage canopy cover, leaf litter and dense undergrowth (Daltry \& Day, 1997). This correlates with the microhabitats in which Watts' anoles are most abundant (Smith \& Baum, 2000).

\section{Threats}

The Antiguan racer evolved on the islands of the Antigua Bank and should not be presumed to be naturally adapted to existing as a tiny population on a 9.9-ha islet. The carrying capacity of Great Bird Island appears to be only about 100 Antiguan racers, which is far below any reasonably expected Minimum Viable Population size (see Soulé, 1996). This small population size means that demographic stochastic effects and loss of genetic variation caused by inbreeding and/or genetic drift are almost inevitable (Lande, 1980; Caughley, 1994). Loss of genetic variation can result in inbreeding depression, a phenomenon that may be characterized by reduced growth rate, fertility, fecundity, resistance to disease and offspring viability (Charlesworth \& Charlesworth, 1987; Madsen et al., 1996). Already, more than 20 per cent of Antiguan racers display what appear to be congenital deformities, including deformed jaws and abnormally fused scales, which may be indicative of inbreeding in insular snake populations (Schwaner, 1990).

Perhaps more important in the short term, however, are the many external threats to the population, including hurricanes (which cause flooding of lowland parts of the island), invasive mammalian predators (rats and mongooses), fluctuating prey numbers and human disturbance. Up to 20,000 people visit Great Bird Island every year, mostly tourists from the USA and Western Europe. As many as 400 visitors have been recorded on the island simultaneously, equivalent to 40 per hectare (Daltry, 1999). Unfortunately, there are no genuine ecotourism operations and no money from tourism feeds directly back to support conservation activities. Few visitors are aware that the island is occupied by one of the world's rarest animals, and most fear or dislike snakes (Daltry, 1999; McCauley, 1999a).

In addition to cases of people deliberately killing Antiguan racers, the mere presence of such large crowds may disrupt essential feeding, reproduction and thermoregulatory behaviours (see Liddle, 1997). There is also increasing actual and potential habitat damage through general trampling, mowing of grass, collecting firewood and allowing campfires to burn out of control; and the constant influx of recreation boats brings a serious risk of rats or other invasive mammals becoming reintroduced. Expatriate visitors in particular often let their dogs run loose on Great Bird Island. 


\section{Conservation action}

Invasive species control

As noted above, many of the racers seen in 1995 showed signs of permanent damage by black rats and, given the severity of the injuries, we presumed that at least some snakes had been killed. Rats were abundant on Great Bird Island in late 1995 and it was not unusual to see them above ground, even during the hottest part of the day. The rats were also observed destroying the eggs of ground-nesting birds, including the globally threatened West Indian whistling duck Dendrocygna arborea (Day \& Daltry, 1996a).

Removing these alien species from Great Bird Island was therefore an urgent priority. Dr Alan Buckle, Rodenticide Technical Manager of Zeneca Agrochemicals, visited the island in late 1995 and advised the ARCP organizations on appropriate risk assessment and eradication protocols. The rodenticide brodifacoum (Klerat ${ }^{\mathrm{TM}}$, Zeneca Agrichemicals, Haslemere, U.K.), a second-generation anticoagulant, was selected: this is highly toxic to rats and, when impregnated into a bitter-tasting waxblock, unpalatable to indigenous birds and reptiles. Brodifacoum is susceptible to degradation by soil bacteria, so any bait getting into the ecosystem would be broken down into inert components within a year. The Great Bird Island rat eradication took 7 days, using 730 bait stations at 10-m intervals (Day \& Daltry, 1996b).

Since 1995, the ARCP has eradicated rats and, where present, mongooses, from a further nine offshore islands (e.g. Varnham et al., 1998). The presence of rats on these islands is checked at least twice a year, chiefly by planting $30-\mathrm{cm}$ lengths of vegetable oil-soaked dowling wood in the ground and leaving them for several nights (rat activity is indicated by gnaw marks). To date, none of the restored islands appear to have been successfully reinvaded.

The eradication programme is intended to (a) reduce the risk of mammals re-colonizing Great Bird Island by developing a buffer zone of rat- and mongoose-free islands around it and (b) make islands available for Antiguan racer re-introductions in the future. As well as invasive predators, several offshore islands also support large non-indigenous herbivores (sheep, goats, fallow deer and until 1995, llamas) that have a negative impact upon forest growth and regeneration. These should be removed and the forest cover restored before Antiguan racers are re-introduced.

\section{Conservation breeding}

In February 1996, three female and two male Antiguan racers were transported to Jersey Zoo as part of a captive breeding feasibility study. The racers bred within the first year, producing 11 eggs of which five were fertile and hatched (Gibson, 1997).

Important data concerning the species's husbandry, activity patterns and reproductive biology - such as clutch size, egg size, gestation and incubation period, and hatchling size - were gained from this feasibility study (Broad, 1996; Gibson, 1997). The Antiguan racer proved to be a somewhat fussy feeder, however, refusing mice or chicks and accepting only live lizards or a specialized artificial diet (Dinosaur Nutrition's Snake Steak ${ }^{T M}$ sausages, Dinosaur Nutrition Ltd, U.K.). More seriously, it appeared that the species displayed a fatal allergic response to even very low loads of the common snake mite Ophionyssus natricis. Despite the best efforts of the zoo's curators and veterinarians, only one racer now survives in captivity, this being kept in strict isolation. This female will not be returned to the wild, but could be a useful tool in the ARCP education programme (see below).

\section{Education and awareness}

Snakes are among the most difficult animals to conserve because the general public and decision-makers frequently dislike and even fear them (Dodd, 1993). Two species of snakes are known from Antigua and Barbuda: the secretive and worm-like Typhlops monastus, which occurs on several islands in the Lesser Antilles and is not considered threatened, and the Antiguan racer. When the project started in 1995, few Antiguans and even fewer tourists were aware that Antigua had any snakes at all, and attitudes towards snakes in general were extremely negative. In the absence of information to the contrary, people finding Antiguan racers on Great Bird Island assumed them to be dangerous, and a common reaction was to kill them. This problem was compounded by the ease with which the snakes could be approached.

The ARCP is endeavouring to bring the plight of the Antiguan racer and the value of its habitat to the attention of local people, tourists and policy makers. The two local project partner organizations - the Environmental Awareness Group and Forestry Unit - have largely led the education efforts to date. In addition to public talks and organized field trips to Great Bird Island, the 'Antiguan Racer Schools Campaign' has entailed numerous visits to schools throughout Antigua to enable local children to learn about conservation and get a close look at a live Antiguan racer (McCauley, 1999a). Morgan \& Gramann (1989) demonstrated greatly improved attitudes and awareness among people who were exposed to snakes and also provided with information: providing information alone, or direct contact 
with snakes alone, had no effect other than increasing knowledge.

Other awareness-raising efforts have included a televised documentary about the Antiguan racer, articles in newspapers and magazines, postings on the internet, radio interviews and tour operator training workshops (e.g. McCauley, 1999b). Tourists pose a particularly great threat to wildlife on Great Bird and other offshore islands, therefore, the ARCP is helping local tour operators to develop their own code of conduct to conserve the natural beauty and biodiversity of these islands. It is, after all, in the long-term interest of Antigua's high-profile tourism industry to use these natural resources sustainably.

\section{Research}

The ARCP monitors the Antiguan racer's population size, behavioural ecology, body condition and demographic structure for at least 5 weeks every year. These data are essential for evaluating whether our conservation activities are proving effective, and for determining how many snakes could safely be removed to establish additional populations.

In the absence of invasive predators such as rats and mongooses, the single most important factor constraining snake numbers appears to be the number and size of prey. As part of the ARCP, the Black Hills State University is spearheading a 5-year research programme on several offshore islands to help understand lizard population dynamics and ecological needs, and to identify new areas that could sustain Antiguan racers. Lizard densities are systematically and non-invasively assessed using randomly situated linear transects and survey points (Smith \& Baum, 2000). This research is linked to the invasive species control programme, in helping to document the recovery of vegetation and lizard populations following the removal of rats and mongooses.

The partner organizations of the ARCP have been documenting and monitoring the biodiversity of the offshore islands (e.g. Horwith \& Lindsay, 1997; Lindsay \& Horwith, 1997). Efforts have especially focused on Great Bird Island, where nesting West Indian whistling ducks and red-billed tropic birds Phaethon aethereus have been studied for the past 5 years. The Environmental Awareness Group is assisting local students to develop projects to gather data on terrestrial and marine wildlife, including the Critically Endangered hawksbill turtle Eretmochelys imbricata, queen conch Strombus gigas and spiny lobster Panulirus argus.

In addition to biological studies, the ARCP has been studying human use of the offshore islands and recently implemented formal questionnaires to help understand the expectations and attitudes of local and international visitors to Great Bird Island (Shadbolt, 2000). These data will be used to help develop appropriate education materials for the various stakeholder groups.

\section{Reintroduction}

Many threats face the Antiguan racers on Great Bird Island, not the least of which is the problem that the island is probably too small to support more than 100 individuals in the long term. It is imperative that this Critically Endangered species is enabled to increase its numbers as quickly as possible, but establishment of captive colonies does not yet appear to be a viable option (see above). Reintroduction to 'mainland' Antigua is also not realistic in the near future, because it would be virtually impossible to control invasive predators across such a large area.

The ARCP therefore plans to reintroduce the species to other small offshore islands on the Antigua Bank in accordance with the guidelines of the IUCN/SSC Reintroduction Specialist Group (IUCN, 1998). Antiguan racers probably originally inhabited all or most of Antigua's offshore islands, which were connected by land bridges approximately 10,000 years ago. According to local people, racers could still be found on some of these islands as recently as the 1970s, but none have been seen here since. The fragmented populations were probably driven to extinction by a combination of factors; for example, invasive predators, genetic inbreeding and stochastic events. A trial re-introduction was carried out in November 1999, whereby five male and five female racers of various sizes were translocated from Great Bird Island to a 2-ha uninhabited island nearby (its name will be kept secret to protect the snakes). This island was selected on the basis of its welldeveloped forest cover, high density of prey, absence of mongooses, close proximity to Great Bird Island and because it is not significantly affected by flooding during hurricanes. Black rats were successfully eradicated from the island in 1998.

Five of the 10 translocated racers were implanted with miniature radiotransmitters to enable their progress to be closely monitored for the first 6 months after release. A more detailed account of this reintroduction will be published elsewhere, but it appears that this new colony is thriving. Two of the females were found to have almost tripled in body mass when they were recaptured in April 2000 and an intensive search for juveniles will be carried out in 2001. A second reintroduction, to a 9-ha rat-free island $<2 \mathrm{~km}$ from Great Bird Island, is scheduled to take place towards the end of 2000 . 


\section{Discussion}

\section{Evaluation of conservation action to date}

Of all the conservation actions attempted, removal of invasive mammals from offshore islands appears to have had the single most positive impact on the Antiguan racer population. It has also benefited many other threatened indigenous species. The number of redbilled tropic birds on Great Bird Island, for example, has more than doubled from about 6 pairs in 1995 to 15 pairs in 2000 (Ross, 2000). The reproductive output of the globally threatened West Indian whistling ducks has also improved dramatically during this period: most clutches found on rat-infested islands are destroyed, whereas hatching success is almost 100 per cent on ratfree islands (unpublished data). Perhaps more surprisingly, we have also witnessed significant increases in vegetation biomass and diversity following rat eradications (e.g. Daltry, 1999).

The ARCP education programme has undoubtedly helped to draw national attention to this previously poorly-known snake and its habitat. In a recent questionnaire-based survey, 26 per cent of independent visitors to Great Bird Island said that they first heard of the racers through this programme (Shadbolt, 2000). As an encouraging indication of how public attitudes are changing, the Antiguan racer was recently pictured on the Antigua and Barbuda EC $\$ 50$ telephone card and, more significantly, conservation of the Antiguan racer will be prioritized in the forthcoming National Biodiversity Strategy and Action Plan.

Also, in the 5 years since the ARCP was formed, much has been learned of the behaviour and population dynamics of the Antiguan racers. With most of the individuals tagged and many even known by sight, this population has become one of the best documented groups of free-living snakes anywhere. The present number of Antiguan racers is substantially higher now than when the project began in 1995 (Fig. 2). The species is still Critically Endangered, however, and its present numbers are on a par with the Critically Endangered Javan rhino Rhinoceros sondaicus. Clearly, the ARCP still has a long way to go before the long-term future of this species can be considered secure.

\section{Threats to the success of this project}

A SWOT ('Strengths, Weaknesses, Opportunities, Threats') analysis by the partner organizations in 1999 identified several serious threats to this project. Of particular concern is raising sufficient funds to conserve what is a traditionally unpopular animal. Many of the activities described in this paper could not have taken place without the personal investment of project staff and volunteers.

A related problem is the lack of capacity within Antigua and Barbuda to implement all aspects of this project. Certain components, such as monitoring the racer population, are still chiefly dependent on foreign expertise. Provision of training and support for Antiguans and Barbudans is therefore a priority objective to ensure the long-term sustainability of the ARCP and other biodiversity conservation projects in this country.

It is also proving difficult to find suitable areas where the Antiguan racer can safely be reintroduced. Although public attitudes are improving steadily, few landowners are willing to allow Antiguan racers to be reintroduced to their islands, even those that are not permanently inhabited by people. Most landowners fully support the removal of harmful invasive rats and mongooses, however, which would at least benefit the West Indian whistling duck and other threatened wildlife.

\section{Future actions}

At the last annual planning meeting in St John's, Antigua, the ARCP partner organizations prioritized the following activities to conserve the Antiguan racer:

- develop and enforce protective national and international legislation for the Antiguan racer and its habitat

- reintroduce the Antiguan racer to offshore islands within its former distribution range

- continue to enhance awareness of the Antiguan racer and its plight among the general public, tour operators, tourists, national decision-makers and potential sponsors

- continue to monitor the size, condition and demography of the wild Antiguan racer population

- continue to implement a research project to survey and monitor lizards on Great Bird Island and other offshore islands

- build local capacity in conservation techniques through training and provision of essential equipment

- continue the ecological restoration of the offshore islands, especially the eradication of invasive species

- endeavour to establish a captive breeding population of Antiguan racers, when technical problems can be overcome.

\section{Relevance to other species conservation programmes}

Alsophis antiguae is just one of 11 species of this genus in the West Indies, of which A. sanctaecrucis (St Croix) and $A$. ater (Jamaica) are probably already extinct 
(Henderson \& Powell, 1999). Alsophis rijersmai (Anguilla Bank) and $A$. rufiventris (St Kitts Bank and Saba) are already listed as Endangered by IUCN (1996), while most of the supposedly non-threatened species have vanished from much of their original distribution ranges. For example, $A$. portoricensis has been extirpated from St Thomas, A. melanichnus from Hispaniola and $A$. antillensis from Marie-Galante (Henderson, 1992). It is largely because of the startling decline in the genus Alsophis over the past 100 years that Dodd (1993) observed that the highest priority region for snake conservation concern today is the West Indies.'

This region also includes Endangered and Critically Endangered colubrid snakes of the genera Ialtris, Chironius and Liophis (IUCN, 1996; Powell et al., 2000). For example, the Barbados racer Liophis perfuscus, which is probably already extinct (Underwood et al., 1999), and the Saint Lucia racer $L$. ornatus, which survives as a relict population on a 10-ha island off the South coast of St Lucia (Corke, 1987).

In most cases, the blame can be firmly pinned on the introduction of predators such as rats, cats and especially mongooses (Henderson \& Sajdak, 1986), but human persecution also plays a part (Censky \& Kaiser, 1999). We hope that the skills and experience generated by the ARCP could be usefully applied to developing a series of similar snake conservation projects throughout the Caribbean.

\section{Acknowledgements}

The Government of Antigua and Barbuda is gratefully acknowledged for enabling this conservation project to take place. We also thank our colleagues for their active support, especially Carole McCauley, Kim Derrick and Foster Derrick (EAG), Sylvia O'Dell and Gail Thacker (FFI), Richard Gibson and Kevin Buley (DWCT), Ryan Baum (BHSU) and Bruce Horwith (IRF), as well as Adriel Thibou and all the staff in the Forestry Unit. Over the past 4 years, a number of additional people have helped in the field with research on the racers and/or invasive species control. In alphabetical order, they are: Mike Appleton, John Cancalosi, Neel Chattopadhyaya, Katherine Dixon, Dr Neil Ford, Andrea Lamboo, Gerard Gray, Aldrick Nicholas, Toby Ross and Karen Varnham.

The Durrell Wildlife Conservation Trust and Fauna \& Flora International have largely funded the project to date, with considerable in-country support from the Environmental Awareness Group, Island Resources Foundation and the Forestry Unit. The Black Hills State University, Columbus Zoo Conservation Fund and the John Ball Zoo Society have funded research on lizards and training of local counterparts. Other groups that have donated funding or equipment are Cable \&
Wireless (West Indies), Lindeth Charitable Trust, Mitchell Charitable Trust, Sarnia Charitable Trust, Bernhardine Fund, Roger Vere Foundation, Walt Disney Conservation Foundation, AVID (UK) plc, Holohil Systems Ltd, Zeneca Agrochemicals plc and the Iris Darnton Award for International Nature Conservation (Whitley Award Scheme). The Energy Science \& Environment Department of the UK Foreign \& Commonwealth Office provided catalytic funding for the first field survey in 1995. British Airways has generously provided several return flights to the UK under the British Airways Assisting Conservation scheme and has transported essential equipment to Antigua. This project has also benefited from assistance from The Natural History Museum, London, and Dr Wolfgang Wüster and Prof. Roger S. Thorpe of the University of Wales, Bangor.

\section{References}

ARCP (Antiguan Racer Conservation Project) (1999) Re-introduction of the Antiguan racer, Alsophis antiguae (Serpentes: Colubridae), to offshore islands around Antigua, West Indies. Proposal to the IUCN/SSC Re-introduction Specialist Group. Fauna \& Flora International, Cambridge.

Begon, M. (1979) Investigating Animal Abundance. Edward Arnold, London.

Broad, G. (1996) Preliminary Study of Activity in Captive Antiguan Racers (Alsophis antiguae) at Jersey Wildlife Preservation Trust. Unpublished Report, JWPT Research Department, Jersey.

Caughley, G. (1994) Directions in conservation biology. Journal of Animal Ecology, 63, 215-244.

Censky, E.J. \& Kaiser, H. (1999) The Lesser Antillean fauna. In Caribbean Amphibians and Reptiles (ed. B. I. Crowther), pp. 181-221. Academic Press, San Diego.

Charlesworth, D. \& Charlesworth, B. (1987) Inbreeding depression and its evolutionary consequences. Annual Review of Ecology and Systematics, 18, 237-268.

Cooper, G., Derrick, F., Derrick, K., McCauley, C., Lindsay, K. \& Cooper, B. (1998) Post-Hurricane Georges Assessment. Report to the Antiguan Racer Conservation Project, Environmental Awareness Group, St Johns, Antigua.

Corke, D. (1987) Reptile conservation on the Maria Islands (St Lucia, West Indies). Biological Conservation, 40, 263-279.

Daltry, J.C. (1999) Status, Distribution and Natural History of the Antiguan Racer (Alsophis antiguae): Field Research and Conservation Technical Report. Antiguan Racer Conservation Project Report No. 4. Fauna \& Flora International, Cambridge.

Daltry, J.C. \& Day, M.L. (1997) Conservation biology of the Antiguan racer (Alsophis antiguae). In Abstracts of the Third World Congress of Herpetology 2-10 August 1997, Prague, p. 49. Third World Congress of Herpetology, Prague, Czech Republic.

Day, M.L. \& Daltry, J.C. (1996a) Antiguan Racer Conservation Project. Fauna and Flora News, April, 6.

Day, M.L. \& Daltry, J.C. (1996b) Rat eradication to save the Antiguan racer. Aliens (Journal of the IUCN/SSC Invasive Species Specialist Group), 3, 14-15. 
Dodd, C.K. Jr (1993) Strategies for snake conservation. In Snakes: Ecology and Behavior (eds R. A. Seigel and J. T. Collins), pp. 363-393. McGraw-Hill, New York.

Gibson, R. (1997) Conservation of the Antiguan racer Alsophis antiguae: the captive component. Proceedings of the 1997 International Herpetological Society Symposium, International Herpetological Society.

Henderson, R.W. (1989) A new subspecies of Alsophis antiguae (Serpentes: Colubridae) from Great Bird Island (Antigua), Lesser Antilles. Caribbean Journal of Science, 25, 119-122.

Henderson, R.W. (1992) Consequences of predator introductions and habitat destruction on amphibians and reptiles in the PostColumbus West Indies. Caribbean Journal of Science, 28, 1-10.

Henderson, R.W. \& Powell, R. (1999) West Indian herpetoecology. In Caribbean Amphibians and Reptiles (ed. B. I. Crother), pp. 223-268. Academic Press, San Diego.

Henderson, R.W. \& Sajdak, R.A. (1986) West Indian racers: a disappearing act or a second chance? Lore, 36, 13-18.

Henderson, R.W., Powell, R., Daltry, J.C. \& Day, M.L. (1996) Alsophis antiguae Parker. Catalogue of American Amphibians and Reptiles, 632, 11-13.

Horwith, B. \& Lindsay, K. (1997) A Biodiversity Profile: Antigua, Barbuda, Redonda. Eastern Caribbean Biodiversity Programme Biodiversity Publication 3, Island Resources Foundation.

IUCN (1996) 1996 IUCN Red List of Threatened Animals. IUCN, Gland and Cambridge.

IUCN (1998) IUCN Guidelines for Reintroductions. Prepared by the IUCN/SSC Re-introduction Specialist Group. IUCN, Gland and Cambridge.

Lande, R. (1980) Genetic variation and phenotypic evolution during allopatric speciation. American Zoologist, 116, 463-479.

Lazell, J.D. Jr (1967) Wiederentdeckung von zwei angeblich ausgestorbenen Schlangenarten der westindischen Inseln. Salamandra, 3, 91-97.

Liddle, M. (1997) Recreation Ecology. Chapman \& Hall. London.

Lindsay, K. \& Horwith, B. (1997) A Vegetation Classification: Antigua, Barbuda, Redonda. Eastern Caribbean Biodiversity Programme Biodiversity Publication 2, Island Resources Foundation.

Madsen, T., Stille, B. \& Shine, R. (1996) Inbreeding depression in an isolated population of adders Vipera berus. Biological Conservation, 75, 113-118.

McCauley, C. (1999a) Environmental Education Status Report. Antiguan Racer Conservation Project, Report No. 6. Environmental Awareness Group, St Johns, Antigua.

McCauley, C. (1999b) Report on Offshore Island Workshop for Tour Operators. Environmental Awareness Group, St Johns, Antigua.

Morgan, J.M. \& Gramann, J.H. (1989) Predicting effectiveness of wildlife education programs: a study of students' attitudes and knowledge towards snakes. Wildlife Society Bulletin, 17, 501-509.

Parker, H.W. (1936) Some extinct snakes of the West Indies. Annals and Magazine of Natural Histology, 18, 227-233.
Powell, R., Ottenwalder, J.A., Incháustegui, S.J., Henderson, R.W. \& Glor, R.E. (2000) Amphibians and reptiles of the Dominican Republic: species of special concern. Oryx, 34, 118-128.

Pregill, G.K., Steadman, D.W. \& Waters, D.R. (1994) Late Quaternary vertebrate faunas of the Lesser Antilles: historical components of Caribbean biogeography. Bulletin of Carnegie Museum of Natural History, 30, iv +51 pp.

Ross, T.N. (2000) Antiguan Racer Population Census 2000. Antiguan Racer Conservation Project, Report No. 7. Fauna \& Flora International, Cambridge.

Sajdak, R.A. \& Henderson, R.W. (1991) Status of West Indian racers in the Lesser Antilles. Oryx, 25, 33-38.

Schwaner, T.D. (1990) Geographic variation in scale and skeletal anomalies of tiger snakes (Elapidae: Notechis scutatusater complex) in southern Australia. Copeia, 1990, 1169-1173.

Schwartz, A. \& Henderson, R.W. (1991) Amphibians and Reptiles of the West Indies: Descriptions, Distributions, and Natural History. University of Florida Press, Gainesville.

Shadbolt, A. (2000) An Analysis of Recreational Users on Great Bird Island. Environmental Awareness Group, St John's, Antigua.

Shine, R. (1993) Sexual dimorphism in snakes. In Snakes: Ecology and Behavior (eds R. A. Seigel and J. T. Collins), pp. 49-86. McGraw-Hill, New York.

Smith, B.E. \& Baum, R. (2000) Surveys of the Lizards Anolis wattsi and Ameiva griswoldi on Antiguan Offshore Islands I: Summer 1999. Antiguan Racer Conservation Project, Report No. 5. Black Hills State University, Spearfish, South Dakota.

Soulé, M.E. (1996) Viable Populations for Conservation. Cambridge University Press, Cambridge.

Southwood, T.R.E. (1966) Ecological Methods. Methuen and Co., London.

Underwood, G., Horrocks, J.A. \& Daltry, J.C. (1999) A new snake from Barbados. Journal of the Barbados Museum and Historical Society, 45, 67-75.

Varnham, K., Ross, T., Daltry, J., Day, M., Cooper, G. \& Lindsay, K. (1998) Recovery of the Antiguan racer. Aliens (Journal of the IUCN/SSC Invasive Species Specialist Group), 8, 21.

\section{Biographical sketch}

Jenny Daltry is a conservation biologist with Fauna \& Flora International, specializing in biodiversity surveys and the management of critically endangered species. She gained her PhD from the University of Aberdeen for research on Asian pit vipers and has spent the past 12 years working on a diverse range of wildlife conservation projects in the Indian Subcontinent, South-east Asia and the Caribbean. Dr Daltry is the UK Co-ordinator of the Antiguan Racer Conservation Project and recently received the Iris Darnton Award for International Wildlife Conservation. 